\title{
Role of intrafollicular regulators and FSH in growth and development of large antral follicles in sheep
}

\author{
L. P. Cahill*, M. A. Driancourt*†, W. A. Chamley $\ddagger$ and J. K. Findlay \\ *Animal Research Institute, Werribee, Victoria, 3030; $\$$ Arthur Rylah Institute, Heidelberg, Victoria 3084; \\ and \$Medical Research Centre, Prince Henry's Hospital, St Kilda Road, Melbourne, Victoria 3004, \\ Australia
}

\begin{abstract}
Summary. Manipulation of circulating concentrations of hormones and ovarian follicle status was carried out on Day 11-12 of the oestrous cycle in sheep. All follicles visible on the ovary were ablated by cautery and ewes were treated with oestradiol or ovine follicular fluid (oFF) to suppress FSH or with PMSG to increase circulating gonadotrophic activity. One group underwent unilateral ovariectomy which greatly increased endogenous FSH and was the only treatment which significantly affected LH pulse frequency. The size distribution of antral follicles, the extent of atresia and the mitotic index of granulosa cells of follicles on Day 15 showed that (a) treatment with oFF inhibited the growth of follicles beyond $2 \mathrm{~mm}$ diameter by suppressing the mitotic index of the granulosa cells and (b) the concentration of FSH in peripheral plasma was related to the ability of small antral follicles to grow during the late luteal-early follicular phase of the cycle.

Subsequently, it was demonstrated that oFF inhibits, in a dose-dependent manner, folliculogenesis sustained by PMSG in ewes on Days 12-15. Inhibition of folliculogenesis was represented by a decrease in those follicles $>4 \mathrm{~mm}$, an increase in the relative proportion of follicles $<2 \mathrm{~mm}$, and minimal change in the average number of follicles visible on the ovarian surface, and a decrease in the mitotic index of granulosa cells of follicles $<2 \mathrm{~mm}$. There was no change in the extent of atresia. This supports the concept of a mitotic inhibitor present in charcoal-treated oFF, which can act at the ovarian level to prevent follicles passing beyond $2 \mathrm{~mm}$ diameter, even in the presence of excess exogenous gonadotrophin. Such a factor could be involved in selection of the follicle(s) destined to ovulate.
\end{abstract}

\section{Introduction}

Follicular growth and development is believed to be under the control of the pituitary gonadotrophins, FSH and LH (Richards, 1980; Baird \& McNeilly, 1981). The mechanism by which individual follicles are selected for ovulation is unknown, although there is evidence that once established these dominant follicles suppress development of other antral follicles (diZerega \& Hodgen, 1981). One hypothesis proposes that dominant follicles reduce the availability of gonadotrophic support to other antral follicles by increasing the feedback inhibition of pituitary secretion of FSH with oestradiol and inhibin (Baird, 1983). A second, but not mutually exclusive, hypothesis is that there are ovarian regulators which act at the ovarian level to modify the number of large antral follicles allowed to develop (Hammond, 1981).

$\dagger$ Present address: INRA, Physiologie de la Reproduction, 37380 Nouzilly, France. 
We sought evidence for this concept by investigating ovine follicular fluid as a potential source of a non-steroidal inter- and intra-ovarian regulator. All follicles visible on the ovarian surface of ewes were ablated by electrocautery on Day 12 (Day $0=$ day of oestrus) to reduce variability between sheep with respect to antral follicles $>0.5 \mathrm{~mm}$ and to enhance the growth potential of the remaining follicles. The extent of growth and atresia of the remaining follicles was observed $72 \mathrm{~h}$ later after treatments which varied circulating gonadotrophin and ovine follicular fluid concentrations. Preliminary results have been reported (Cahill, Chamley \& Findlay, 1983).

\section{Materials and Methods}

Animals and reagents. Three experiments were conducted at the Animal Research Institute, Werribee between March and May (mid-breeding season). Different Corriedale ewes in good condition and 5-6 years of age from the same flock were used in each experiment. The ewes were treated in the late luteal-early follicular phase of the cycle after oestrus which had been synchronized using intravaginal sponges (Repromap-MAP, Upjohn). Oestrus (Day 0 ) was detected by vasectomized rams fitted with harnesses and crayons and the ewes were checked daily.

The follicular fluid for injection was aspirated from follicles visible on sheep ovaries which had been collected at random from a slaughterhouse. In Exp. 1, whole follicular fluid was used, whilst in Exps 2 and 3 the follicular fluid was treated with dextran-coated charcoal $(1 \mathrm{mg} / \mathrm{ml}$ final concentration) to remove free steroids (Tsonis et al., 1983).

Experiment 1. This experiment investigated the influence of ovine follicular fluid and gonadotrophins on growth of antral follicles during the late luteal-early follicular phase of the oestrous cycle.

Ewes (6 groups of 9-10) were studied from Day 12 until Day 15 when ovariectomy was carried out. The six treatment groups were: Group 1, untreated ewes; Group 2, on Day 12 the reproductive tract was exteriorized while ewes were under general anaesthesia and all follicles visible (i.e. $>0.5 \mathrm{~mm}$ ) on the surface of the ovary were ablated by electrocautery; Group 3, follicles were cauterized as in Group 2 and a Silastic capsule containing $100 \mathrm{mg}$ oestradiol-17 $\beta$ (Sigma, Melbourne, Australia) was implanted s.c. for Days 12-15; Group 4, follicles were cauterized as in Group 2 and 500 i.u. PMSG (Pregnecol, Beresford Laboratories, Melbourne, Australia) was administered i.m. on the morning of Day 12; Group 5, follicles on the ovary containing the corpus luteum were cauterized as in Group 2 and the contralateral ovary was removed (unilateral ovariectomy); Group 6, follicles were cauterized as in Group 2 and whole ovine follicular fluid were injected s.c. in 1.5 ml doses at 08:00 and 16:00 h, commencing at 16:00 h on Day 11 and continuing each day until ovariectomy.

At ovariectomy, the number of follicles visible on the surface of ovaries was recorded and the diameter of each follicle was estimated to the nearest $\mathrm{mm}$ by comparison with a steel sphere of known diameter. All follicles that were $>4 \mathrm{~mm}$ and $2-4 \mathrm{~mm}$ diameter and 10 follicles per group that were $<2 \mathrm{~mm}$ were examined for atresia and mitotic index of the granulosa cells. Follicles were dissected out and placed in Bouin-Hollande's fixative. Later the follicles were embedded, and sections cut at $7 \mu \mathrm{m}$ were mounted and stained with Feulgen's stain. Atresia was defined by the presence of any pycnotic bodies in a follicle on the section where the nucleolus of the nucleus of the oocyte was observed; the mitotic index is expressed as the percentage of mitotic figures observed in 2000 cells chosen at random in a follicle.

Blood samples were collected from the jugular vein, immediately centrifuged and the plasma was stored at $-15^{\circ} \mathrm{C}$ until assayed. Samples were taken twice daily $(08: 00$ and 16:00 h) from Days 12 to 15 to determine the FSH concentration during the experimental period. Blood samples for LH estimations were taken every $15 \mathrm{~min}$ for a 6-h period on Day 13. 
Experiment 2. This experiment investigated the effect of different doses of charcoal-treated ovine follicular fluid, given to ewes with and without PMSG, on the growth of antral follicles in the late luteal-early follicular phase of the oestrous cycle. The experimental design consisted of 8 groups each of 7-8 ewes with 2 doses of PMSG ( 0 and 500 i.u.) and 4 doses of follicular fluid $(0,1,2$ and $4 \mathrm{ml}$ per day) (Table 3 ).

On Day 12 of the cycle after a synchronized oestrus, all visible follicles on the surface of the ovary were ablated by electrocautery as described in Exp. 1. Immediately after the operation, 29 ewes were treated with 500 i.u. PMSG and the remaining ewes were left untreated. The total dose of follicular fluid per day was administered in two equal amounts at 08:00 and 16:00 h each day starting at 16:00 h Day 11 and ending at 08:00 on Day 15. Ovariectomy and examination of follicles was performed on Day 15 as described for Exp. 1.

Experiment 3. This experiment investigated the effect of a high dose of PMSG administered with charcoal-treated ovine follicular fluid on follicular growth and oestrous behaviour. There were 4 treatment groups each with 17-18 ewes in a $2 \times 2$ design ( 2 doses of PMSG, 0 and 1500 i.u., and 2 doses of follicular fluid, 0 and $4 \mathrm{ml} /$ day; Table 5). Each group had 2 equal subgroups, with ewes in one subgroup undergoing ovariectomy on Day 15 to study the effects on folliculogenesis and those in the other subgroup being observed for oestrous behaviour to study the interval from cautery to oestrus.

On Day 12 all visible follicles on the surface of each ovary of all ewes were destroyed by electrocautery as in Exp. 1. Immediately following the operation 1500 i.u. PMSG were given i.m. to half the ewes and the remainder were untreated. Ewes treated with ovine follicular fluid received $4 \mathrm{ml}$ per day as in Exp. 2.

At ovariectomy the diameter and number of visible follicles on the ovaries were recorded and histological preparation and examinations were carried out as previously described. The ewes in the remaining subgroups were run with harnessed vasectomized rams on Day 15 and inspected twice daily until oestrus was observed.

Hormone assays. The data for all hormone assays were computed by the method of Burger, Lee \& Rennie (1972).

Concentrations of LH in plasma were measured by radioimmunoassay (Lee et al., 1976) using NIH-LH-S1 8 as standard. All samples in 8 assays were read on that portion of the standard curve where the within-assay coefficient of variation (CV) was $<10 \%$, between $3.1 \pm 0.8$ and $21.4 \pm 3.5 \mathrm{ng} / \mathrm{ml}$ (mean \pm s.d.). At maximum precision, the within-assay $\mathrm{CV}$ was $7 \cdot 0 \pm 0 \cdot 8 \%$ (s.d.), and the sensitivity was $0.48 \pm 0.07 \mathrm{ng} / \mathrm{ml}$. Between-assay CV was $3.9 \%$ at $9.28(0.36)$ and $14.5 \%$ at $11.48(1.66) \mathrm{ng} / \mathrm{ml}$. Although PMSG is known to cross-react in this assay and therefore LH concentrations in the PMSG-treated group could be overestimated, it is still possible to determine the frequency of LH pulses. An LH pulse was defined (Clarke, Wright, Chamley \& Burman, 1984) as having occurred if the assay value of a particular sample exceeded the assay value of the previous sample by more than 3 times the s.d. of the assay value of the previous sample (s.d. given by the computation of the assay data).

Concentrations of FSH in plasma samples were measured in one radioimmunoassay (Bremner, Findlay, Lee, de Kretser \& Cumming, 1980) using NIH-FSH-S6 as standard. All samples were read on that portion of the standard curve where the within-assay CV was $<10 \%$, between 44 and $900 \mathrm{ng} / \mathrm{ml}$. The assay had a maximum precision of $6.0 \%$ and the sensitivity was $13.3 \mathrm{ng} / \mathrm{ml}$. PMSG does not cross-react in this radioimmunoassay for FSH (Lee, McMaster, Quigg, Findlay \& Leversha, 1981).

Statistical analysis. $\mathbf{R} \times \mathbf{C}$ tests of independence were used to examine whether the proportion of follicles in each size class was independent of treatments, and the G-test of independence of 2 treatments was used to examine the goodness of fit of the observed frequencies to their expectation (Sokal \& Rohlf, 1981). The data on plasma FSH and LH and mitotic index were subjected to 
analysis of variance, and comparisons of follicle number between treatments were made by Duncan's multiple range $F$ test.

\section{Results}

\section{Experiment 1}

Follicle data. The number of visible follicles per ewe in each treatment group and their distribution within size groups varied significantly between treatments (Table 1). The untreated ewes (Group 1) had more visible follicles on the ovarian surface on Day 15 than any of the groups in which cautery was performed. Cautery plus PMSG (Group 4) resulted in a larger proportion of follicles $>4 \mathrm{~mm}$ diameter compared to cautery alone (Group 2), whereas cautery plus oestradiol (Group 3) resulted in relatively few follicles $>4 \mathrm{~mm}$. After cautery plus follicular fluid (Group 6) there were no follicles $>4 \mathrm{~mm}$ and only $11.4 \%>2 \mathrm{~mm}$ on Day 15 ; no other treatments significantly affected the relative proportion of follicles $2-4 \mathrm{~mm}$ except unilateral ovariectomy (Group 5) in which there was a slight increase.

Table 1. The distribution of follicles visible on the ovarian surface amongst size groups and mitotic index (MI) of granulosa cells on Day 15 after electrocautery of visible follicles on Day 12 of the cycle and various treatments administered from Days 11 to 15 (Exp. 1)

\begin{tabular}{|c|c|c|c|c|c|c|c|}
\hline \multirow[b]{2}{*}{ Group } & \multirow[b]{2}{*}{ Treatment } & \multirow{2}{*}{$\begin{array}{l}\text { No. of } \\
\text { ewes }\end{array}$} & \multirow{2}{*}{$\begin{array}{l}\text { Visible } \\
\text { follicles/ } \\
\text { ewet }\end{array}$} & \multicolumn{3}{|c|}{ Follicle Size Distribution (\%) } & \multirow{2}{*}{$\begin{array}{r}\text { MI }(\%) \\
(>4 \mathrm{~mm}\end{array}$} \\
\hline & & & & $<2 \mathrm{~mm}$ & $2-4 \mathrm{~mm}$ & $>4 \mathrm{~mm}$ & \\
\hline 1 & Untreated & 10 & $17 \cdot 8+2 \cdot 20^{\mathrm{a}}$ & $60 \cdot 7$ & $24 \cdot 7$ & $14 \cdot 6$ & $0.48^{\mathrm{a}}$ \\
\hline 2 & Cautery & 10 & $5 \cdot 8 \pm 1 \cdot 07^{\mathrm{bc}}$ & $46 \cdot 6$ & $25 \cdot 9$ & $27 \cdot 6$ & $1.04^{\mathrm{b}}$ \\
\hline 3 & $\begin{array}{l}\text { Cautery+ } \\
\text { oestradiol }\end{array}$ & 10 & $4 \cdot 5 \pm 0.50^{\mathrm{bc}}$ & $67 \cdot 4$ & $23 \cdot 9$ & $8 \cdot 7$ & $0.94^{\mathrm{b}}$ \\
\hline 4 & $\begin{array}{c}\text { Cautery + } \\
\text { PMSG }\end{array}$ & 10 & $7 \cdot 9 \pm 1 \cdot 31^{\mathrm{b}}$ & $20 \cdot 3$ & $21 \cdot 5$ & $58 \cdot 2$ & $1.03^{b}$ \\
\hline 5 & $\begin{array}{l}\text { Cautery+ } \\
\text { unilateral } \\
\text { ovariectomy } \\
\text { Cautery+ }\end{array}$ & 10 & $2 \cdot 8 \pm 0 \cdot 98^{\mathfrak{c}}$ & $46 \cdot 4$ & $32 \cdot 1$ & $21 \cdot 4$ & $1 \cdot 49^{\mathrm{c}}$ \\
\hline 6 & $\begin{array}{c}\text { Cautery + } \\
\text { oFF }\end{array}$ & 9 & $4 \cdot 9 \pm 1 \cdot 39^{\mathrm{bc}}$ & $88 \cdot 6$ & $11 \cdot 4$ & 0 & - \\
\hline
\end{tabular}

${ }^{*} \mathrm{R} \times \mathrm{C}$ test of independence, $\mathrm{G}=99.96$, d.f. $=10, P<0.001$.

$\uparrow$ Values are mean \pm s.e.m.

Values in columns with different superscripts differ at the $5 \%$ level of significance.

The number of atretic follicles per ovary was reduced $(P<0.05)$ in all ewes that underwent cautery and was directly related to the number of follicles in each size class (data not shown). No follicles $>4 \mathrm{~mm}$ were atretic in ewes in which unilateral ovariectomy was performed (Group 5).

The mitotic index of the granulosa cells on Day 15 varied significantly $(P<0.05)$ between treatment groups for follicles $>4 \mathrm{~mm}$ (Table 1), but not for follicles $<2 \mathrm{~mm}$ or $2-4 \mathrm{~mm}$. In follicles $>4 \mathrm{~mm}$, the mitotic index was higher in all ewes that underwent cautery compared to controls, particularly in the group in which unilateral ovariectomy was performed (Group 5). There were no follicles $>4 \mathrm{~mm}$ in Group 6 in which to determine mitotic index.

Hormone data. There were significant differences $(P<0.01)$ in mean concentrations of FSH in plasma between groups $\left(F_{5,216}=42 \cdot 4\right)$ and between days $\left(F_{3,216}=6 \cdot 77\right)$, and the interaction of days $\times$ groups was equally significant $\left(F_{15,216}=3 \cdot 86\right)$ (Table 2). Untreated ewes (Group 1) main- 
Table 2. Daily mean concentrations of FSH and the number of LH pulses during $6 \mathrm{~h}$ on Day 13 in plasma of ewes in Exp. 1

\begin{tabular}{|c|c|c|c|c|c|c|c|}
\hline \multirow[b]{2}{*}{$\begin{array}{l}\text { Day of } \\
\text { cycle }\end{array}$} & \multicolumn{6}{|c|}{ Treatment } & \multirow[b]{2}{*}{$\begin{array}{l}\text { Mean } \\
\text { (per } \\
\text { day) }\end{array}$} \\
\hline & $\begin{array}{l}\text { Group 1 } \\
\text { (control, } \\
\mathrm{N}=10 \text { ) }\end{array}$ & $\begin{array}{l}\text { Group } 2 \\
\text { (cautery, } \\
\mathrm{N}=10 \text { ) }\end{array}$ & $\begin{array}{c}\text { Group } 3 \\
\text { (cautery } \\
+ \\
\text { oestradiol, } \\
\mathrm{N}=10 \text { ) }\end{array}$ & $\begin{array}{c}\text { Group } 4 \\
\text { (cautery } \\
+ \\
\text { PMSG, } \\
\mathrm{N}=10 \text { ) }\end{array}$ & $\begin{array}{c}\text { Group } 5 \\
\text { (cautery } \\
+ \\
\text { unilat. Ovx., } \\
\mathrm{N}=10 \text { ) }\end{array}$ & $\begin{array}{c}\text { Group } 6 \\
\text { (cautery } \\
+ \\
\text { oFF, } \\
\mathrm{N}=9 \text { ) }\end{array}$ & \\
\hline \multicolumn{8}{|c|}{ Mean FSH conc. per day $(\mathrm{ng} / \mathrm{ml})^{*}$} \\
\hline 12 & 63 & 101 & 67 & 89 & 107 & 58 & 81 \\
\hline 13 & 53 & 151 & 76 & 86 & 230 & 33 & 106 \\
\hline 14 & 50 & 92 & 71 & 33 & 181 & 31 & 76 \\
\hline 15 & 64 & 86 & 86 & 26 & 141 & 28 & 72 \\
\hline \multicolumn{7}{|l|}{ Mean \pm s.e.m. } & $83 \pm 6$ \\
\hline \multicolumn{8}{|c|}{ Number of LH pulses per $6 h \dagger$} \\
\hline 13 & $2 \cdot 2 \pm 0 \cdot 3^{\mathrm{a}}$ & $2 \cdot 1 \pm 0 \cdot 7^{\mathrm{a}}$ & $1 \cdot 9 \pm 0 \cdot 5^{a}$ & $2 \cdot 1 \pm 0 \cdot 3^{a}$ & $4 \cdot 9 \pm 0 \cdot 3^{b}$ & $3 \cdot 3 \pm 0 \cdot 5^{\mathrm{a}}$ & \\
\hline
\end{tabular}

* Least Significant Difference $(P<0 \cdot 05)=51 \cdot 6$.

$\uparrow$ Different superscripts denote significant differences $(P<0.05)$ according to Duncan's multiple range $\mathrm{F}$ test.

tained a relatively constant daily mean FSH concentration from Day 12 to Day 15, whereas in groups of ewes that underwent cautery (Group 2) or cautery plus unilateral ovariectomy (Group 5) there was a marked transient increase in plasma FSH, particularly on Day 13, followed by a decrease. Ewes in Group 6 (cautery plus follicular fluid) showed a sustained but not significant decrease in plasma concentrations of FSH from Day 13 to Day 15. Ewes treated with oestradiol (Group 3) had FSH concentrations resembling those in Group 2 (cautery alone), while in those treated with PMSG (Group 4), FSH concentrations were initially higher and then decreased significantly by Day 15.

There were significantly $(P<0.05)$ more LH pulses in plasma of ewes in Group 5 (cautery plus unilateral ovariectomy) on Day 13 than in the other groups (Table 2).

\section{Experiment 2}

PMSG did not have a significant effect on the growth of follicles after cautery in the presence or absence of ovine follicular fluid, and there were no significant effects of treatment on visible follicles/ewe (Table 3). Treatment with follicular fluid resulted in an initial increase in follicles of 2-4 mm diameter and then a dose-dependent decrease in the proportion of follicles 2-4 mm and $>4 \mathrm{~mm}$ diameter and an increase in the proportion of follicles $<2 \mathrm{~mm}$, irrespective of treatment with PMSG (Table 3). At the highest dose of follicular fluid (4 ml/day), only $2 / 74$ visible follicles $>2 \mathrm{~mm}$ diameter were present on the ovarian surface on Day 15 in all ewes examined.

Any effect PMSG may have had on mitotic indices of granulosa cells was not apparent on Day $15(1.64 \pm 0.05$ and $1.64 \pm 0.05 \%$ for follicles $<2 \mathrm{~mm}$, and $1.22 \pm 0.11$ and $1.35 \pm 0.09 \%$ for follicles $>2 \mathrm{~mm}$, with 500 and 0 i.u. PMSG, respectively). In contrast, the mitotic indices of granulosa cells in follicles $<2 \mathrm{~mm}$ from ewes treated with follicular fluid decreased $(P<0.05)$ in a dose-dependent manner $(0 \mathrm{ml}, 1.86 \pm 0.08 \% ; 1 \mathrm{ml}, 1.70 \pm 0.07 \% ; 2 \mathrm{ml}, 1.50 \pm 0.07 \% ; 4 \mathrm{ml}$, $1.54 \pm 0.07 \%$ ). The mitotic indices in follicles $>2 \mathrm{~mm}$ did not differ after treatment with ovine follicular fluid.

There was no significant effect of PMSG or follicular fluid on the incidence of atresia (data not shown). 
Table 3. The effect of dose of charcoal-treated ovine follicular fluid (oFF) and PMSG on antral follicles visible on the sheep ovary (Exp. 2)

\begin{tabular}{|c|c|c|c|c|c|c|}
\hline \multicolumn{2}{|c|}{ Treatment } & \multirow{3}{*}{$\begin{array}{l}\text { No. of } \\
\text { ewes }\end{array}$} & \multirow{3}{*}{$\begin{array}{c}\text { Visible } \\
\text { follicles/ewe† }\end{array}$} & \multirow{2}{*}{\multicolumn{3}{|c|}{ Follicle size distribution $(\%)^{*}$}} \\
\hline \multirow{2}{*}{$\begin{array}{l}\text { PMSG } \\
\text { (i.u.) }\end{array}$} & \multirow{2}{*}{$\begin{array}{c}\mathrm{oFF} \\
(\mathrm{ml} / \text { day })\end{array}$} & & & & & \\
\hline & & & & $<2 \mathrm{~mm}$ & $2-4 \mathrm{~mm}$ & $>4 \mathrm{~mm}$ \\
\hline 0 & 0 & 7 & $6 \cdot 9 \pm 1 \cdot 32$ & $70 \cdot 2$ & $8 \cdot 5$ & $21 \cdot 3$ \\
\hline 0 & 1 & 8 & $5.3 \pm 0.88$ & $66 \cdot 7$ & 19.0 & $14 \cdot 3$ \\
\hline 0 & 2 & 7 & $6.0 \pm 0.72$ & 75.0 & $12 \cdot 5$ & $12 \cdot 5$ \\
\hline 0 & 4 & 7 & $4.6 \pm 0.76$ & $93 \cdot 8$ & $6 \cdot 2$ & 0 \\
\hline 500 & 0 & 7 & $5 \cdot 0 \pm 0 \cdot 87$ & $57 \cdot 1$ & $8 \cdot 6$ & $34 \cdot 3$ \\
\hline 500 & 1 & 7 & $6 \cdot 3 \pm 1 \cdot 17$ & $63 \cdot 6$ & 15.9 & $20 \cdot 5$ \\
\hline 500 & 2 & 8 & $4.8 \pm 0.99$ & $86 \cdot 8$ & 7.9 & $5 \cdot 3$ \\
\hline 500 & 4 & 7 & $6.0 \pm 0.91$ & $100 \cdot 0$ & 0 & 0 \\
\hline
\end{tabular}

${ }^{*} \mathrm{R} \times \mathrm{C}$ test of independence, $\mathrm{G}=53 \cdot 71$, d.f. $=14, P<0 \cdot 001$.

$\dagger$ Mean \pm s.e.m.

Table 4. The effect of a high dose of PMSG on the ability of ovine follicular fluid (oFF) to inhibit folliculogenesis in the sheep ovary (Exp. 3)

\begin{tabular}{|c|c|c|c|c|c|c|}
\hline \multicolumn{2}{|c|}{ Treatment } & \multirow{3}{*}{$\begin{array}{l}\text { No. of } \\
\text { ewes }\end{array}$} & \multirow{3}{*}{$\begin{array}{c}\text { Visible } \\
\text { follicles/ewe } \dagger\end{array}$} & \multirow{2}{*}{\multicolumn{3}{|c|}{ Follicle size distribution $(\%)^{*}$}} \\
\hline \multirow{2}{*}{$\begin{array}{l}\text { PMSG } \\
\text { (i.u.) }\end{array}$} & \multirow{2}{*}{$\begin{array}{l}\text { oFF } \\
\text { (ml/day) }\end{array}$} & & & & & \\
\hline & & & & $<2 \mathrm{~mm}$ & $2-4 \mathrm{~mm}$ & $>4 \mathrm{~mm}$ \\
\hline 0 & 0 & 7 & $4.6 \pm 0.84$ & $59 \cdot 4$ & 21.9 & $18 \cdot 8$ \\
\hline 1500 & 0 & 8 & $6.8 \pm 1.22$ & $49 \cdot 1$ & 17.0 & $34 \cdot 0$ \\
\hline 0 & 4 & 8 & $4.9 \pm 0.79$ & 100 & 0 & 0 \\
\hline 1500 & 4 & 6 & $6.2 \pm 0.79$ & $89 \cdot 2$ & $5 \cdot 4$ & 5.4 \\
\hline
\end{tabular}

${ }^{*} \mathrm{R} \times \mathrm{C}$ test of independence, $\mathrm{G}=328.07$, d.f. $=6, P<0.001$.

$\dagger$ Mean \pm s.e.m.

\section{Experiment 3}

Effects on folliculogenesis. The high dose (1500 i.u.) of PMSG increased both the proportion $(P<0.001)$ (Table 4$)$ and number $(P<0.05)$ of follicles $>4 \mathrm{~mm}$ (PMSG, $1.4 \pm 0.29$ follicles/ewes; no PMSG, $0.4 \pm 0.27$ ), but this dose of PMSG was unable to prevent follicular fluid significantly reducing the proportion of visible follicles $>2 \mathrm{~mm}$ while concomitantly increasing the proportion $<2 \mathrm{~mm}$. There was no significant change in the total number of visible follicles/ewe (Table 4). As observed in Exp. 2, no apparent effects of PMSG on mitotic indices of granulosa cells (range $1 \cdot 25-1 \cdot 57 \%$ ) were seen on Day 15 . Treatment with follicular fluid resulted in a significant reduction in the mitotic index of granulosa cells from $<2 \mathrm{~mm}$ follicles $(1.73 \pm 0.07 \%$ vs $1.46 \pm 0.06 \%, P<0.01$ ). There were too few follicles $>2 \mathrm{~mm}$ after follicular fluid treatment to make an accurate estimate of mitotic index.

There was no significant effect of PMSG or follicular fluid on the incidence of atresia of follicles in any size class studied on Day 15 (data not shown).

Effects on oestrus. PMSG had no significant effect on the mean interval from 08:00 h on Day 15 (i.e. 3 days after cautery) to the time oestrus was first observed (PMSG 55 h; no PMSG, 51 h; mean cycle length $17 \cdot 2$ days). Treatment with follicular fluid was followed by a significant delay $(P<0.05)$ in the display of oestrus, the interval being 95 and $105 \mathrm{~h}$ (mean cycle length 19.2 days) for ewes treated with and without PMSG, respectively. 


\section{Discussion}

This study has shown that charcoal-treated ovine follicular fluid, in addition to its ability to suppress secretion of FSH by the pituitary (Cummins, O'Shea, Bindon, Lee \& Findlay, 1983) also contains a factor(s) which can inhibit follicular growth sustained by PMSG. Furthermore, this study has shown that the ability of small antral follicles to grow during the late luteal-early follicular phase of the sheep oestrous cycle is related to the concentration of FSH in peripheral plasma.

In Exp. 1, it was shown that enhanced follicular growth, indicated by a change in the size distribution of follicles in favour of those $>4 \mathrm{~mm}$ diameter, was associated with increased concentrations of FSH. When the rise in FSH associated with cautery was blunted by including oestradiol, the extent of follicular growth by Day 15 was not as great. The increase in folliculogenesis was not accompanied by a significant change in the LH pulse frequency, except in the group in which unilateral ovariectomy was performed. Therefore, the data support a role for FSH in determining follicular growth rates, possibly in follicles $<2 \mathrm{~mm}$, in the late luteal phase when $\mathrm{LH}$ pulse frequency is low (Findlay \& Cumming, 1977; Baird, 1983).

The removal of all visible follicles by cautery on Day 12 was associated in all groups with an increase in the mitotic index of granulosa cells of large follicles on Day 15, particularly in the group in which unilateral ovariectomy was performed. This increase in mitotic index cannot be attributed solely to FSH stimulation because it was still present in the follicles in the group treated with oestradiol, in which FSH concentrations were similar to untreated controls. The increase in mitotic index after cautery in this group could have been due to a direct action of oestradiol known to induce mitosis in rodent granulosa cells (Richards, 1980). Alternatively, cautery of follicles may have removed an endogenous inhibitor of granulosa cell division which was present in follicular fluid. Treatment with follicular fluid $(4 \mathrm{ml} /$ day) after cautery virtually abolished all follicles $>2 \mathrm{~mm}$, an effect which could have been mediated by the inhibin activity in the follicular fluid suppressing FSH (Cummins et al., 1983) or by a direct action of the follicular fluid at the ovarian level.

The subsequent experiments provided further evidence for a factor(s) in follicular fluid that can act at the ovarian level. The dose-dependent inhibition by follicular fluid of folliculogenesis sustained by PMSG is consistent with the presence of a mitotic inhibitor in charcoal-treated ovine follicular fluid which acts at the ovary to prevent follicles passing beyond $2 \mathrm{~mm}$ diameter, despite the presence of PMSG. We have recently shown that this activity in follicular fluid can also be demonstrated in hypophysectomized ewes treated with PMSG, confirming a direct effect at the ovarian level (Cahill et al., 1985).

Injection of bovine or ovine follicular fluid around the time of luteolysis in sheep will delay oestrus and ovulation (Miller, Critser, Rowe \& Ginther, 1979; Cummins, Bindon, O'Shea \& Piper, 1980), an observation confirmed in this study. However, it was believed that this action of follicular fluid was mediated by the presence of inhibin activity which will suppress FSH in sheep (Cummins et al., 1983) rather than by a direct action on the ovary.

The inhibitor in ovine follicular fluid is unlikely to be a steroid because the activity remained after charcoal treatment, and it is either very potent or has a long half-life because only relatively small doses of follicular fluid (1-4 ml/day) given s.c. to sheep were required to inhibit folliculogenesis. Many factors with a wide range of biological activities have been described in follicular fluid but few have been fully characterized (Hammond, 1981). Activity which will stimulate cell growth and division is present in follicular fluid, but little attention has been paid to inhibitors of cell division in comparison to inhibitors of gonadotrophin binding, steroidogenesis and oocyte maturation. Human (diZerega, Marrs, Roche, Campeau \& Kling, 1983a) and pig follicular fluid (Kling et al., 1984) and ovarian venous blood from the human ovary containing the dominant follicle (diZerega, Goebelsmann \& Nakamura, 1982) possess activity which will inhibit PMSG-induced folliculogenesis in hypophysectomized, immature rats. This is thought to be an 
inhibitor of aromatase activity in the granulosa cell (diZerega et al., 1983b; Kling et al., 1984) rather than an inhibitor of cell division.

Collectively, these studies support the concept of an ovarian factor involved in selection of the dominant follicle. It raises the interesting question of how the dominant follicle, if it is the ovarian source of the inhibitor, is itself influenced by the inhibitor. From early in the antral phase, as the antrum and follicular fluid content of a follicle increases, the mitotic index of the granulosa cells decreases to almost zero in preovulatory follicles (Turnbull, Braden \& Mattner, 1977; Cahill \& Mauleon, 1980). Therefore the number of granulosa cells increases only slightly despite increasing follicular diameter (McNatty, 1982; Tsonis, Carson \& Findlay, 1984). This decrease in the mitotic index of granulosa could be due to increased concentrations of an inhibitor in follicular fluid. The presence of a local intra- or inter-ovarian regulatory agent could also be involved in several other aspects of folliculogenesis which are difficult to explain simply by changes in the pattern or concentrations of the gonadotrophins. There is evidence that ovulation occurs from alternate ovaries in primates (diZerega \& Hodgen, 1981; Gougeon \& Lefevre, 1983) despite perfusion of each ovary by the same amount of gonadotrophins, which suggests direct communication between the ovaries. Unilateral ovariectomy in the ewe results in a transient rise in plasma FSH 6-12 h later but the FSH concentrations then return to presurgical levels although ovulation rate from the remaining ovary is doubled and remains so (Findlay \& Cumming, 1977). Many attempts have been made to relate circulating FSH and LH concentrations to ovulation rate in the sheep (Scaramuzzi \& Radford, 1983) but without much success, suggesting that other factors may be involved in determining the number of eggs shed. In a histological examination of all growing follicles in both right and left ovaries, Cahill, Mariana \& Mauleon (1979) found that the number of small preantral follicles varied greatly between the two ovaries, but as follicle size increased, the numbers of follicles per class were similar in each ovary which could mean that, as follicles grow larger, the communication between ovaries increases.

In conclusion, this study provides evidence for a role of extra- and intra-gonadal factors in the control of folliculogenesis in the sheep ovary, a key extragonadal factor being FSH and the intragonadal factor(s) with putative antimitotic activity being present in follicular fluid.

We thank Peter Langdon, Paul Weston, Carl Tuohey, Con Tsonis, Trevor Gill, Karen Rees, Therese Loel and Najuva Fatmous for technical assistance; Julie Coleman and Diane Hollingsworth for preparing the manuscript; and NIAMDD and Dr Leo Reichert Jr for standards for the gonadotrophin assays. The study was supported by grants from the Australian Wool Research Trust Fund and the National Health and Medical Research Council of Australia.

\section{References}

Baird, D.T. (1983) Factors regulating the growth of the preovulatory follicle in the sheep and human. $J$. Reprod. Fert. 69, 343-352.

Baird, D.T. \& McNeilly, A.S. (1981) Gonadotrophic control of follicular development and function during the oestrous cycle of the ewe. J. Reprod. Fert., Suppl. 30, 119-133.

Bremner, W.J., Findlay, J.K., Lee, V.W.K., de Kretser, D.M. \& Cumming, I.A. (1980) Feedback effects of the testis on pituitary responsiveness to LHRH infusion in the ram. Endocrinology 106, 329-336.

Burger, H.G., Lee, V.W.K. \& Rennie, G.C. (1972) A generalised computer program for the treatment of data from competitive binding assays including radioimmunoassays. J. lab. clin. Med. 80, 302-312.

Cahill, L.P. \& Mauleon, P. (1980) Influences of season, cycle and breed on follicular growth rates in sheep. $J$. Reprod. Fert. 58, 321-328.
Cahill, L.P., Mariana, J.C. \& Mauleon, P. (1979) Total follicular populations in ewes of high and low ovulation rates. J. Reprod. Fert. 55, 27-36.

Cahill, L.P., Chamley, W.A. \& Findlay, J.K. (1983) Hormonal control of follicles in the ovine follicular phase. Proc. Aust. Soc. Reprod. Biol. 15, 78, Abstr.

Cahill, L.P., Clarke, I.J., Cummins, J.T., Driancourt, M.A., Carson, R.S. \& Findlay, J.K. (1985) An inhibitory effect at the ovarian level of ovine follicular fluid on PMSG-induced folliculogenesis in hypophysectomized ewes. In Proc. 5th Ovarian Workshop, pp 35-38. Eds D. Toft \& R. J. Ryan. Plenum Press, New York.

Clarke, I.J., Wright, P.J., Chamley, W.A. \& Burman, K. (1984) Differences in the reproductive endocrine status of ewes in the early post-partum period and during seasonal anoestrus. J. Reprod. Fert. 70, 591-597. 
Cummins, L.J., Bindon, B.M., O'Shea, T. \& Piper, L.R. (1980) Effects of ovine follicular fluid given during induced luteolysis in control and Booroola Merinos. Proc. Aust. Soc. Reprod. Biol. 12, 50, Abstr.

Cummins, L.J., O'Shea, T., Bindon, B.M., Lee, V.W.K. \& Findlay, J.K. (1983) Ovarian inhibin content and sensitivity to inhibin in Booroola and control strain Merino ewes. J. Reprod. Fert. 67, 1-7.

diZerega, G.S. \& Hodgen, G.D. (1981) Folliculogenesis in the primate ovarian cycle. Endocr. Rev. 2, 27-49.

diZerega, G.S., Goebelsmann, U. \& Nakamura, R.N. (1982) Identification of protein(s) secreted by the preovulatory ovary which suppresses the follicular response to gonadotrophin. J. clin. Endocr. Metab. 54, 1091-1096.

diZerega, G.S., Marrs, R.P., Roche, P.C., Campeau, J.D. \& Kling, O.R. (1983a) Identification of proteins in pooled human follicular fluid which suppresses follicular response to gonadotrophins. J. clin. Endocr. Metab. 56, 35-41.

diZerega, G.S., Campeau, J.D., Nakamura, R.N., Ujita, E.L., Lobo, R. \& Marrs, R.P. (1983b) Activity of a human follicular fluid protein(s) in spontaneous and induced ovarian cycles. J. clin. Endocr. Metab. 57, $838-846$.

Findlay, J.K. \& Cumming, I.A. (1977) The effect of unilateral ovariectomy on plasma gonadotropin levels, estrus and ovulation rate in sheep. Biol. Reprod. 17, 178-183.

Gougeon, A. \& Lefevre, B. (1983) Histological evidence of alternating ovulation in women. $J$. Reprod. Fert. 70, 7-13.

Hammond, J.M. (1981) Peptide regulators in the ovarian follicle. Aust. J. biol. Sci. 34, 491-504.

Kling, O.R., Roche, P.C., Campeau, J.D., Nishimura, K., Nakamura, R. \& diZerega, G.S. (1984) Identification of a porcine follicular fluid fraction which suppresses follicular response to gonadotropins. Biol. Reprod. 30, 564-572.

Lee, V.W.K., Cumming, I.A., De Kretser, D.M., Findlay, J.K., Hudson, B. \& Keogh, E.J. (1976) Regulation of gonadotrophin secretion in rams from birth to sexual maturity. Plasma LH, FSH and testosterone levels. $J$. Reprod. Fert. 46, 1-6.
Lee, V.W.K., McMaster, J., Quigg, H., Findlay, J.K. \& Leversha, L. (1981) Ovarian and peripheral blood inhibin concentrations increase with gonadotropin treatment in immature rats. Endocrinology 108, $2403-2405$.

McNatty, K.P. (1982) Ovarian follicular development from the onset of luteal regression in humans and sheep. In Follicular Maturation and Ovulation, pp. 1-18. Eds R. Rolland, E. N. van Hall, S. G. Hillier, K. P. McNatty \& J. Shoemaker. Excerpta Medica, Amsterdam.

Miller, K.F., Critser, J.K., Rowe, R.F. \& Ginther, O.J. (1979) Ovarian effects of bovine follicular fluid treatment in sheep and cattle. Biol. Reprod. 21, 537-544.

Richards, J.S. (1980) Maturation of ovarian follicles: actions and interactions of pituitary and ovarian hormones on follicular cell differentiation. Physiol. Rev. 60, 51-89.

Scaramuzzi, R.J. \& Radford, H.M. (1983) Factors regulating ovulation rate in the ewe. J. Reprod. Fert. 69, 353-367.

Sokal, R.R. \& Rohlf, F.J. (1981) Biometry: The Principles and Practice of Statistics in Biological Research, 2nd edn. W.H. Freeman \& Co., San Francisco.

Tsonis, C.G., Quigg, H., Lee, V.W.K., Leversha, L., Trounson, A.O. \& Findlay, J.K. (1983) Inhibin in individual ovine follicles in relation to diameter and atresia. J. Reprod. Fert. 67, 83-90.

Tsonis, C.G., Carson, R.S. \& Findlay, J.K. (1984) The relationships between aromatase activity, follicular fluid oestradiol-17 $\beta$ and testosterone concentrations and diameter and atresia of individual ovine follicles. J. Reprod. Fert. 72, 153-163.

Turnbull, K.E., Braden, A.W.H. \& Mattner, P.E. (1977) The pattern of follicular growth and atresia in the ovine ovary. Aust. J. biol. Sci. 30, 229-241.

Received 27 April 1985 